\title{
The Legal Politic in Countermeasure the Crime in Funding and Management of Disaster Assistance
}

\author{
Luh Nila Winarni*, Cokorde Istri Dian Laksmi Dewi, Anak Agung Gde Raka, and Ni Putu Tirka Widanti \\ Universitas Ngurah Rai, Bali, Indonesia \\ *nilawinarnihukum@gmail.com
}

Published: 25/02/2021

How to cite:

Winarni, L, N., Dewi, C, I, D, L., Raka, A, A, G., Widanti, N, P, T. 2021. The Legal Politic in Countermeasure the Crime in Funding and Management of Disaster Assistance. Sociological Jurisprudence Journal. Volume 4 Issue 1. Page 31 - 38. https://doi.org/10.22225/ scj.4.1.2265.31-38

\begin{abstract}
Indonesian geographical, geological and hydrological regions are disaster-prone areas. Disaster-prone is the geological, biological, hydrological, climatological, geographical, social, cultural, political, economic and technological conditions or characteristics of a region for a certain period of time that reduce the ability in preventing, reducing, achieving readiness, and reduce the ability to respond to adverse impacts of certain hazards. People's behavior that damages the environment also tends to increase the number of disasters. Seeing such conditions, the government has compiled a policy to allocate budgets for pre-disaster, during emergency response, and post-disaster development. This government policy is also supported by the contributions of community in providing disaster relief. A bad disaster management system can be a gap to commit criminal acts against funds and disaster relief. In this study, two issues will be discussed, namely legal politics in funding and managing disaster relief and the legal consequences of criminal acts in funding and management of disaster relief. The legal politics in disaster relief funding and management are outlined in The Act Number 24 of 2007 concerning Disaster Management and Republic of Indonesia Government Regulation Number 22 of 2008 concerning Funding and Management of Disaster Assistance. The legal consequences of criminal acts of funding and management of disaster assistance are criminal penalties ranging from imprisonment, fines, or capital punishment
\end{abstract}

Keywords: Crime; Disaster; Funds and Assistance; Legal Politics.

\section{INTRODUCTION}

Indonesia is a region that is vulnerable to disasters, both natural disasters and social disasters. Natural and social disasters are influenced by Indonesian geographical, geological, hydrological, demographic, and pluralistic factors that allow disasters to occur. For natural disasters, they are strongly influenced by Indonesian geographical conditions which are located at the confluence of large plates in the world namely, the Eurasian, the Indian-Australian, and the Pacific Plate; and the fact that Indonesia is located in a series of ring of fire. Disasters are also influenced by the behavior patterns of individuals and groups of people who have the lack awareness of the environment, so that it influences the hydroclimatology factor and ecosystem damage (Kartika: 330).

Indonesia has the line of active volcanoes in the world. Indonesia itself has approximately 240 volcanoes, in which nearly 70 of them are still active and most of them are in the East part of Indonesia (Tondobala: 58-63). In the period 1600 to 2000, there have been 105 tsunami events in Indonesia, 90 percent of them are due to tectonic earthquakes and 10 percent are due to volcanic eruptions (https:// tniad.mil.id/2019/01/implementasi-peran-tni-dalam-mitigasi-bencana-guna-mendukung-terwujudnyakewaspadaan-nasional/). Indonesian vulnerability to disaster can be seen from the disaster statistics reported by the National Disaster Management Agency as follows: 
Table 1

Disasters in Indonesia 2019

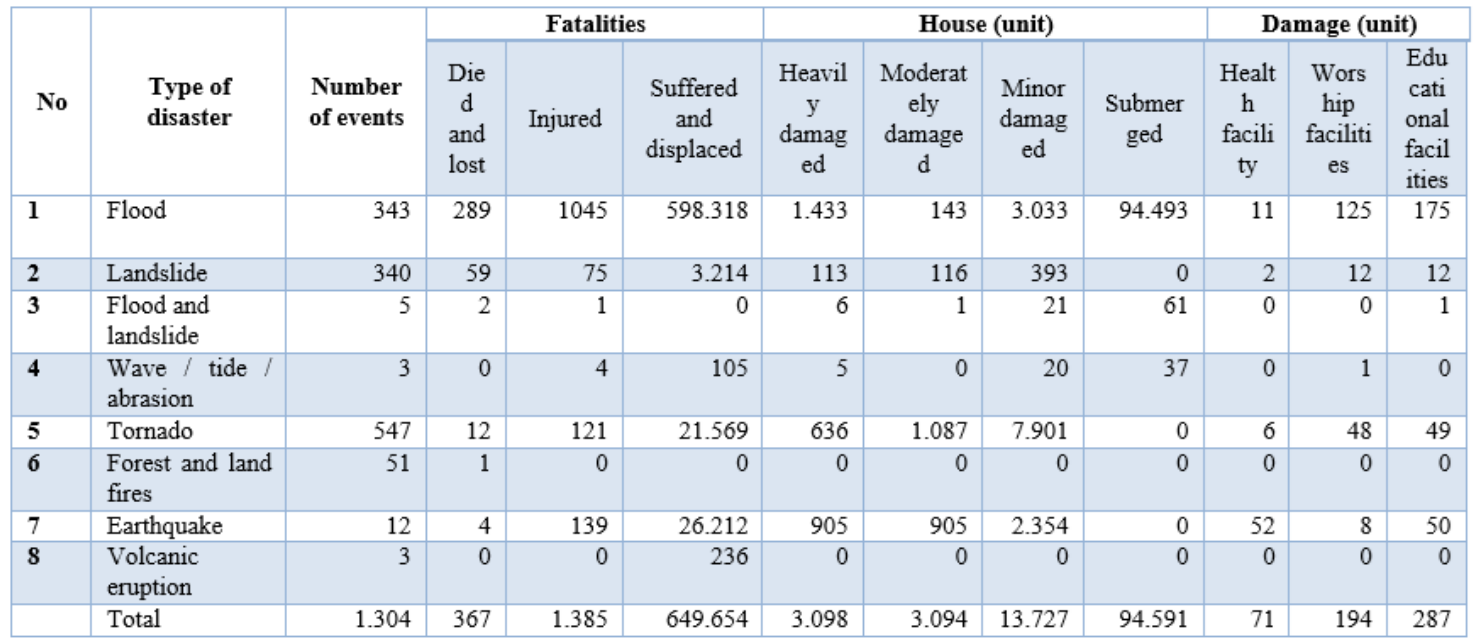

Source: Badan Penanggulangan Bencana Nasional Repulik Indonesia (National Disaster Management Agency of Republic of Indonesia)

The occurrence of disasters certainly requires a progressive response from policy makers to manage funds and build disaster infrastructure. Various disaster detection buildings until evacuation buildings are prepared to minimize casualties and material damage during disasters. Such a large budget prepared to overcome disasters turns out to be one of the objects that are vulnerable to criminal acts, such as corruption and embezzlement of disaster relief funds. Muhammad Hafil inventoryed several corruption cases related to disaster in Indonesia, namely as follows:

The Corruption Eradication Commission (Komisi Pemberantasan Korupsi) caught the hands of a number of government and private officials related to the Drinking Water Supply System project in the earthquake-tsunami disaster affected area in Palu, Central Sulawesi.

The Mataram District Prosecutor's Office arrested a Mataram City Legislative Council member who extorted government officials from the education building renovation project affected by the earthquake in West Nusa Tenggara.

Hand arrest operations carried out by the police against an employee of the Ministry of Religion who carried out illegal levies for the renovation of the mosque affected by the West Nusa Tenggara earthquake.

The corruption case of the handling of the 2006-2007 earthquake-tsunami in Nias carried out by the Nias regent at that time.

Corruption in the Majalengka landslide fund in 2014.

The North Sumatra disaster map corruption and there was a corruption of tsunami shelter in Banten in 2012

Corruption funds for the reconstruction of the impact of the Merapi eruption in Magelang in 2012.

Corruption in tornado handling funds in Serang in 2012.

Mojokerto disaster fund breach in 2013.

Corruption in the Kudus disaster logistics in 2014. Then, there was corruption in the construction of a breakwater in Kolaka in 2012.

Corruption in the Aceh fundraising conference post-tsunami in 2005 (https://republika.co.id/berita/ kolom/fokus/plgszk318/korupsi-di-atas-penderitaan-korban-bencana-alam).

The suffering caused by the disaster is the suffering of all humanity, that is why when a disaster occurs, many people show their concern by collecting money, food, clothes, and materials needed. 
Donations are collected by many parties with non-synergy management. This condition is a gap for certain individuals to use the results of donations for personal gain. The absence of transparency in managing disaster donations will certainly have an impact on the lack of public trust in providing assistance, disaster victims who do not get their rights, and slowing post-disaster recovery.

Misuse of funds and disaster assistance must be responded by the government's legal politics to prevent and punish the perpetrators of these crimes. Substantially, legal politics includes material in the design of legislation (legislative drafting), the implementation of legislation (legal executing), and a review of legislation (legal review) (Hamzah: 24). In this study, two issues will be discussed, namely 1) legal politics in funding and managing disaster relief and 2) the legal consequences of criminal acts of funding and disaster relief management.

\section{METHOD}

This research is about juridical research that analyzes legal politics in funding and managing disaster relief and the legal consequences of criminal acts of funding and disaster relief management. This study uses a descriptive qualitative approach. In qualitative descriptive research, the focus of researchers is to explore actual phenomena, and the nature of the data collected is more natural with rational analytical.

\section{III.DISCUSSION}

\section{The Legal Politic in Funding and Managing Disaster Assistance}

Provisions regarding disasters in Indonesia are regulated in The Act Number 24 of 2007 concerning Disaster Management. This Law has implemented regulations that regulate funding and management of disaster relief as formulated in the Republic of Indonesia Government Regulation Number 22 of 2008 concerning Funding and Management of Disaster Assistance.

According to Article 1 number 1 of The Act Number 24 of 2007 concerning Disaster Management, disasters are events or series of events that threaten and disrupt the lives and livelihoods of people caused by natural factors and / or non-natural factors and human factors resulting in fatalities, environmental damage, property losses, and psychological impacts. The provision formulates several types of disasters, namely:

Natural disasters are disasters caused by events or a series of events caused by nature such as earthquakes, tsunamis, volcanic eruptions, floods, droughts, hurricanes, and landslides.

Non-natural disasters are disasters caused by events or a series of non-natural events which include technological failures, failure of modernization, and epidemics of disease.

Social disasters are disasters caused by events or a series of events that are caused by humans which include social conflicts between groups or between community communities, and terror.

Carter defines disaster as a natural or man-made event, sudden or progressive, which has a large impact so that the affected community must respond with extraordinary actions. Natural disasters are caused by two factors, namely natural disasters that occur due to natural factors and natural disasters caused by human activities (Kodoatie: 2010).

Disasters can be caused by natural disasters or man-made disasters. Factors that can cause disasters include natural and man-made hazards which according to the United Nations International Strategy for Disaster Reduction (UN-ISDR) can be grouped into geological hazards, hydrometeorological hazards, biological hazards, technological hazards and decreasing environmental quality (environmental degradation), high vulnerability from the community, infrastructure and elements in cities / regions at risk of disaster and the low capacity of various components in society (https://www.bnpb.go.id/home/ potensi).

Disaster management activities are basically a series of activities before, during and after a disaster carried out to prevent, reduce, avoid and recover from the effects of disasters (Yayasan: 2007).

Factors of communication, resources, disposition or attitude and structure of the bureaucracy implementing disaster management policies have a significant effect on the success of disaster management implementation. Roni Ekha Putera continues to argue "The problem of disaster a few years 
recently has been an interesting topic of discussion, not only by government but also by non-government organization and society. The unsuspected various aspects of disaster towards disaster is in the future. The way of thinking in disaster management is this present time." (Putera: 2015).

Disaster management is basically a comprehensive effort that requires the role of all parties. Article 4 of The Act Number 24 of 2007 concerning Disaster Management states that disaster management aims to:

provide protection to the community from the threat of disaster;

align existing legislation;

guarantee the implementation of disaster management in a planned, integrated, coordinated and comprehensive manner;

respect local culture;

build public and private participation and partnerships;

encourage the spirit of mutual cooperation, solidarity and generosity; and

create peace in the life of the community, nation, and state.

The central and regional government are responsible for implementing disaster management. The government in this case has the authority to form the National Disaster Management Agency. The National Disaster Management Agency is a non-departmental government institution at the ministerial level consisting of directors of disaster management, and disaster management implementers. According to Article 12 of The Act Number 24 of 2007 concerning Disaster Management, the National Disaster Management Agency has a duty to:

provide guidance and direction on disaster management efforts that include disaster prevention, emergency response, rehabilitation, and reconstruction in a fair and equal manner;

stipulate standardization and needs for the implementation of disaster management based on legislation;

convey information on activities to the community;

report on the implementation of disaster management to the President every once a month under normal conditions and at any time in a state of disaster emergency;

use and account for national and international donations / assistance;

accountable for the use of the budget received from the State Revenue and Expenditure Budget;

carry out other obligations in accordance with legislation; and

draw up guidelines for the establishment of the Regional Disaster Management Agency.

Article 13 of The Act Number 24 of 2007 concerning Disaster Management states that the National Disaster Management Agency has the function of covering:

formulating and stipulating disaster management and refugee handling policies by acting quickly, precisely, effectively, and efficiently; and

coordinating the implementation of planned, integrated and comprehensive disaster management activities.

In principle, the Disaster Management Law has arranged coordination among institutions or agencies that handle disaster management, namely in Article 3 paragraph (2) letter C, which states that one of the principles in disaster management is coordination and integration. In the explanation of the Disaster Management Act states the principle of coordination is that disaster management based on good coordination and mutual support, while the principle of integration is meant that disaster management is carried out by various sectors in an integrated manner based on good cooperation and mutual support (http://ditjenpp.kemenkumham.go.id/hukum-lingkungan/1095-refleksi-pengelolaan-bencana-diindonesia-antara-harapan-dan-realita-suatu-analisis-yuridis.html).

So far, natural disaster management has not been well integrated. It causes the slow handling of disasters in Indonesia. As the result of the government inadequacy in facing the weaknesses of disaster 
management, especially to reduce disaster risk and increase the resilience of the Central Government, Regional Governments, and communities in dealing with disasters, there are several things that need to be done, among others: First, the government needs to make regulations disasters, namely the presidential regulation on the status and level of disasters and other rules regarding disaster risk analysis and minimum service standards, and so forth. Second, the Government needs an innovative disaster risk financing framework to meet the budgetary needs of large-scale disaster management funding and change the management of disaster risk financing into investment schemes as fulfillment of Government obligations. Third, the Government needs to change the scheme of disaster management mechanisms faster, more planned and on target. Fourth, the need for disaster mitigation efforts to reduce disaster risk through physical development and public awareness about disasters through continuous and sustainable socialization. Fifth, there is a need for coordination between ministries and institutions that receive the disaster management mandate (https://berkas.dpr.go.id/puskajianggaran/buletin-apbn/public-file/buletinapbn-public-67.pdf.).

Funds and assistance are very important elements in disaster management. The politics of government law in managing funds and assistance is done by formulating the Republic of Indonesia Government Regulation Number 22 of 2008 concerning Funding and Management of Disaster Assistance. Article 3 of the Government Regulation of the Republic of Indonesia Number 22 of 2008 concerning Funding and Management of Disaster Assistance determines that arrangements for funding and managing disaster relief include:

a. disaster management fund sources;

b. use of disaster management funds;

c. disaster relief management; and

d. supervision, reporting and accountability for disaster relief funding and management.

Disaster management funds are a joint responsibility between the central government and the regional government. The disaster management fund comes from the APBN; APBD; and / or community. Disaster management funds are used in accordance with the implementation of disaster management which includes the pre-disaster, emergency response, and / or post-disaster stages. The government and local government provide disaster assistance to disaster victims. Disaster assistance consists of compensation for condolences, disability compensation, soft loans for productive businesses, and assistance in meeting basic needs.

The government establishes policies in supervision and reports on accountability for funds and disaster relief. In Article 31 of the Republic of Indonesia Government Regulation Number 22 of 2008 concerning Funding and Management of Disaster Assistance stated as follows:

The government, regional government, BNPB or BPBD are in accordance with their authority to carry out supervision and accountability reports on the management of funds and disaster management assistance.

Institutions / institutions associated with BNPB or BPBD supervise the distribution of funds provided by the community to disaster victims.

The government and regional governments carry out oversight of the management of funds and assistance at all stages of disaster management. The report on the accountability of disaster management, both financial and performance at the pre-disaster and post-disaster stages is carried out in accordance with the provisions of the legislation. Accountability for the use of disaster management funds during disaster response is treated specifically in accordance with emergency conditions and carried out in accordance with the principles of accountability and transparency. The report on the accountability of disaster management, both financial and performance during the emergency response is reported no later than 3 (three) months after the emergency response period. Financial reporting of disaster management sourced from the APBN or APBD is carried out according to government accounting standards. The accounting system for community-sourced disaster management funds is carried out according to the guidelines set by the Minister of Finance. All disaster management accountability reports, both financial and performance, are audited in accordance with the laws and regulations 


\section{Legal Consequences in the Crime of Funding and Disaster Relief Management}

As a disaster-prone area, the government has prepared a budget to tackle disasters, starting from the construction of pre-disaster physical facilities to post-disaster budgets. The occurrence of a disaster that claimed lives, endangered human lives, and loss of property will cause concern for the community. To help alleviate disaster victims, the community also plays a role in providing assistance. This assistance can be in the form of cash, daily necessities and material for post-disaster reconstruction.

The amount of the budget is prepared to cope with disasters and incoming assistance from various parties without being balanced with transparent management and effective supervision tends to be a gap for the crime of funds and disaster relief. Wirjono Prodjodikoro states "Crime is an act whose perpetrators can be subject to criminal penalties. This perpetrator can be interpreted as the subject of a crime (Prodjodikoro: 1989)

In the use of funds and disaster assistance, there are at least two possible crimes, namely corruption and misuse of disaster relief resource management. Corruption that often occurs is corruption in the budget for the construction of physical facilities for disaster management. This criminal offense does not only harms state finances, but also violates the social and economic rights of the community (Hamzah: 2005). Corruption in the construction of evacuation buildings, for example, will cause victims who are supposed to be able to take refuge safely, become victims of the disaster. These criminal acts of corruption can be carried out by civil servants, individuals and corporations involved in the construction.

Provisions that can be used if the perpetrator commits corruption against funds and disaster assistance is the provision in Article 2 of The Act Number 31 of 1999 concerning Eradication of Corruption Crime, which states as follows:

Anyone who unlawfully commits an act enriches himself or another person who is a corporation that can harm state finances or the economy of the country, is punished with imprisonment for life or imprisonment for a minimum of 4 (four) years and at most 20 ( twenty) years and a fine of at least Rp. 200,000,000.00 (two hundred million rupiah) and at most Rp. 1,000,000,000.00 (one billion rupiah).

In the event that a criminal act of corruption as referred to in paragraph (1) is carried out in certain circumstances, capital punishment can be imposed.

The phrase "certain circumstances" referred to as written in the explanatory section of Article 2 paragraph (2) of Act Number 31 of 1999 concerning Eradication of Corruption Crime is a condition that can be used as an excuse for criminal offenses if the crime is committed against funds intended for hazard management, national natural disasters, mitigation due to widespread social unrest, economic and monetary crisis mitigation, and repetition of criminal acts of corruption. Referring to the provision, corruption committed against funds and disaster relief can be punished with capital punishment.

Corruption is basically an act of enriching oneself. The elements of self-enrichment are as follows:

The acquisition of wealth

There is the acquisition of wealth beyond the acquisition of a legitimate source of wealth

There is legitimate wealth originating from legitimate wealth sources, and there is unauthorized excess wealth originating from unauthorized sources. It is this illegitimate wealth that is obtained from actions that enrich unlawfully (Hamzah: 2011).

The mechanism for receiving social assistance is currently not well-directed and well-organized. Assistance originating from the community is collected through charities, houses of worship, and communities that can be collected by anyone. Submission of assistance is also often carried out directly into the refugee camps. This less organized system allows community groups to collect funds to abuse the management of disaster relief resources. Such actions are threatened with criminality as formulated in Article 78 of The Act Number 24 of 2007 concerning Disaster Management which states as follows:

Every person who intentionally misuses the management of disaster relief resources as referred to in Article 65, is punished with imprisonment with life imprisonment or imprisonment of at least 4 (four) years or a maximum of 20 (twenty) years and a fine of at least Rp.6,000.000,000.00 (six billion rupiahs) or a maximum fine of Rp. 12,000,000,000.00 (twelve billion rupiah). 
In Article 65 of The Act Number 24 of 2007 concerning Disaster Management determines "Management of disaster relief resources includes planning, using, maintaining, monitoring, and evaluating national and international goods, services, and / or money." Criminal charges against acts in misusing the management of disaster relief resources can be used against corporate actors as stipulated in Article 79 of Law Number 24 of 2007 concerning Disaster Management which states as follows:

In the case of a criminal offense as referred to in Article 75 up to Article 78 carried out by a corporation, in addition to imprisonment and fines for its management, criminal penalties that can be imposed against the corporation are in the form of criminal penalties with 3 (three) charges of criminal penalties referred to in Article 75 to Article 78.

In addition to criminal penalties as referred to in paragraph (1), the corporation may be subject to additional criminal sanctions in the form of:

revocation of business license; or

revocation of legal entity status.

The legal politics in imposing sanctions for perpetrators of crime in funding and managing disaster assistance are carried out to ensure compliance with Law Number 24 of 2007 concerning Disaster Management and at the same time provide a deterrent effect on the parties, both due to negligence and intentional actions causing disasters that cause losses, both on property and the death of people, hampering ease of access in disaster management activities, and misuse of disaster relief resource management.

\section{IV.CONCLUSION}

The legal politics in disaster relief funding and management are outlined in Law Number 24 of 2007 concerning Disaster Management and Republic of Indonesia Government Regulation Number 22 of 2008 concerning Funding and Management of Disaster Assistance. In the management of social assistance, there may be criminal acts, namely corruption and misuse of disaster relief resource management. The legal consequences of criminal acts of funding and management of disaster assistance are criminal penalties ranging from imprisonment, fines, to allowing the imposition of death sentence.

\section{REFERNCES}

Badan Penanggulangan Bencana Nasional. Potensi dan Ancaman Bencana. Tersedia: https://www.bnpb.go.id/ home/potensi

Carolina, M. Kelemahan-Kelemahan Penanggulangan Bencana Alam di Indonesia. Tersedia: https:// berkas.dpr.go.id/puskajianggaran/buletin-apbn/public-file/buletin-apbn-public-67.pdf.

Hafil, M. (2019). Korupsi di Atas Penderitaan Korban Bencana Alam. Tersedia: https://republika.co.id/berita/ kolom/fokus/plgszk318/korupsi-di-atas-penderitaan-korban-bencana-alam

Hamzah, A. (1991) Politik Hukum Pidana. Jakarta: Raja Grafindo Persada.

Hamzah, A. (2005). Perbandingan Korupsi di Berbagai Negara. Jakarta: Sinar Grafika.

Hamzah, A. (2011). Korupsi di indonesia Masalah dan Pemecahnya. Jakarta: Gramedia Pustaka Utama.

Kartika, S.D. (2017). Politik Hukum Penganggulangan Bencana. Kajian. 20 (4), p. 330.

Kementerian Hukum dan Hak Asasi Manusia Republik Indonesia. Refleksi Pengelolaan Bencana Di Indonesia Antara Harapan Dan Realita (Suatu Analisis Yuridis). Tersedia: http://ditjenpp.kemenkumham.go.id/hukum -lingkungan/1095-refleksi-pengelolaan-bencana-di-indonesia-antara-harapan-dan-realita-suatu-analisisyuridis.html

Kodoatie, R.J. \& Sjarief, R. (2010). Tata Ruang Air. Yogyakarta: ANDI.

Prodjodikoro, W. (1989). Asas-Asas Hukum Pidana Indonesia. Bandung: P.T. Eresco.

Putera, R.E., (2015).Implementasi Kebijakan Penanggulan Bencana Berbasis Mitigasi Bencana di Kota Padang, dalam Johan Richard Weintré et.al., Creating ASEAN Futures 2015: Towards Connected Cross-Border Communities, International Indonesian Forum For Asian Studies, Andalas University, 28-29 September 2015.

Setyawan, R.W.P. (2019). Implementasi Peran TNI dalam Mitigasi Bencana Guna Mendukung Terwujudnya Kewaspadaan Nasional, https://tniad.mil.id/2019/01/implementasi-peran-tni-dalam-mitigasi-bencana-gunamendukung-terwujudnya-kewaspadaan-nasional/

Tondobala, L. (2012). Pemahaman Tentang Kawasan Rawan Bencana dan Tinjauan Terhadap Kebijakan dan 
The Legal Politic in Countermeasure the Crime in Funding and Management of Disaster Assistance

Peraturan Terkait. Jurnal Sabua. 3 (1) p. 58-63.

Yayasan IDEP. (2007). Buku Panduan Umum Penanggulangan Bencana Berbasis Masyarakat. Bali. 